\title{
Information Technology Implications of IFRS Implementation in Nigeria: Challenges to Auditors
}

\author{
Daferighe Emmanuel Emekaponuzo ${ }^{1}$, Ofonime Okon Jeremiah ${ }^{2}$, Emah Joseph Alfred ${ }^{1}$ \\ ${ }^{1}$ Department of Accounting, University of Uyo, Uyo, Nigeria \\ ${ }^{2}$ Department of Accounting, Nnamdi Aizikwe University, Awka, Nigeria
}

Email address:

daferighe2e@yahoo.com (D. E. Emekaponuzo), ofmejerry@yahoo.com (O. O. Jeremiah), e_jalfred@yahoo.com (E. J. Alfred)

To cite this article:

Daferighe Emmanuel Emekaponuzo, Ofonime Okon Jeremiah, Emah Joseph Alfred. Information Technology Implications of IFRS Implementation in Nigeria: Challenges to Auditors. Journal of Investment and Management. Vol. 6, No. 1, 2017, pp. $22-27$. doi: $10.11648 /$ j.jim.20170601.14

Received: October 18, 2016; Accepted: November 4, 2016; Published: December 14, 2016

\begin{abstract}
The adoption of IFRS as the reporting standards in Nigeria has brought with it changes in the accounting systems. IT changes is one essential aspect of concern in the IFRS implementation especially considering its effects on audit practice. These issues defined the focus of this paper. The survey research design was adopted. Auditors in audit accounting firms in Anambra and Akwa Ibom states of Nigeria were the targeted respondents. 120 auditors were randomly selected using convenience and judgemental technique. Data were collected using a 5-point Likert scale questionnaire. The data were analysed using the descriptive statistic such as averages, weights and ranking. It was discovered that the technology changes as a result of IFRS implementation requires high IT expertise from auditors as they need to understand the up to date software. It was therefore recommended that auditors should take up the challenge of updating their knowledge and skills with regard to IFRS and information technology in order to brace up for the challenges ahead. Similarly, accountancy training institutions such as tertiary institutions and professional tuition homes should update their curriculum to be in tune with the demands of IFRS; IFRS training packs and software should be made affordable in Nigeria.
\end{abstract}

Keywords: Information Technology, IFRS, IFRS Implementation, Auditors

\section{Introduction}

The progressive adoption and implementation of International Financial Reporting Standards (IFRS) is gradually replacing the different national accounting standards which existed in various countries before now. The introduction of this standard was borne out of the need for a more comprehensive, comprehensible and decision relevant financial reporting that will ensure enhanced comparability across international boundaries. According to [4], Over 120 countries and reporting jurisdictions now either require or allow the use of IFRS for the preparation of financial statements. In Nigeria, the IFRS was adopted as the reporting standards in Nigeria, with effect from January 2012. From that time on, stakeholders have indicated that the adoption and implementation of this standard trigger a wide range of implications not only on financial disclosures but also on other aspects of an organization [7].
[4] pointed out that "as a company prepares to convert to IFRS, the impact on information technology and financial systems should be taken into consideration during the planning phase. Representatives from the company's information technology department should therefore be involved throughout the planning process to evaluate how the proposed accounting changes will impact the financial systems. [8] also noted that while an IFRS conversion begins in the finance and accounting functions, to effectively create an integrated conversion strategy, a company should include the technology function. Information technology structure and changes is therefore one of the very essential element to consider in the pursuit of the IFRS policy implementation.

[2] reiterated that IFRS implementation would bring about changes in many accounting processes and information systems responsible for financial reporting and the preparation of financial statements, which in turn would affect the organization's governance structure and internal control. Hence, it has been indicated that auditors should be 
integrated into the planning of IFRS implementation. The perspective for this submission is that since auditors are to carry out the attested function in cognizance of provisions of the standards, it becomes evident that the information technology issues arising as a result of IFRS implementation would directly or indirectly, affect the practice and perspective of audit. [20] however, noted that some organizations often neglect to consider the full impact of IFRS conversion on their information systems oblivious of the fact that overlooking these issues can result in significant compliance challenges as the years go by.

These issues raise a question which defines the focus of this paper. The paper therefore, mainly sets out to reflect on the question: What are the information technology implications of IFRS implementation to audit practice in Nigeria?

\section{Literature Review}

\subsection{IFRS and Financial Reporting in Nigeria: A Brief Overview}

For several years, the Statements of Accounting Standards (SAS) regulated the practice of financial reporting in Nigeria. These standards were issued by the Nigerian Accounting Standards Board (NASB). However in 2010, the roadmap to convergence with IFRS was enunciated. According to [5], this move was borne out the belief that that it would be in best interest of the nation to adopt IFRS. In pursuit of this, a phased transition spanning a period of three years was therefore adopted. Nigerian listed companies \& Significant Public Interest Entities (SPIEs) were required to comply with IFRS for periods ending after 1st January 2012. Other SPIEs were required to comply for periods ending after 1st January 2013, and small and medium sized entities were slated to comply for periods ending after 1st January 2014. To this end, the NASB was restructured to Financial Reporting Council of Nigeria (FRC) to facilitate an effective adoption and implementation process [19].

Gleanings from studies, sequel to IFRS adoption, indicate that deposit money banks seem to constitute the bulk of institutions in Nigeria that have to a reasonable extent, presently implemented IFRS. The worst culprits are the small and medium scale enterprises (SME). One reason, which could be readily advanced to explain this default, is that the level of preparedness for its implementation by most of the SMEs is less than satisfactory [3]. However, in spite of the much applauded benefits of financial report quality, comparability and expanded investment possibilities, [15] noted that the experiences of these deposit money banks show that there are a lot of difficulties in converging to IFRS in Nigeria. One of such capacity- related difficulties highlighted, is the software problems. Accounting packages that are not compatible with IFRS have to be dropped and new ones that can enable IFRS implementation acquired. The challenge faced here is not only in terms of cost of software acquisition but also that of training personnel to use new packages. All these are related to information technology system structure of the organization.

This constraint, among others constitutes the implications of IFRS implementation and is always cited as limiting factors to the full implementation of IFRS, as planned. There is a need therefore to better appreciate the determinants and dimensions of the impact of this constraint and to ultimately establish how it affects not just financial reporting but also the auditing practice.

\subsection{The Concept of Information Technology}

Information technology refers to the creation, gathering, processing, storage, presentation and dissemination of information and all the processes and devices that enable all these to be done. Concisely, it deals with information system, data storage, access, retrieval, analysis and intelligent decision making.

Information Technology has undoubtedly played a remarkable role in the business sector in recent times. The rapid change in information technology; the widespread of user-friendly systems and the great desire of organizations to acquire and implement up to date computerized systems and software have made computers much easier to be used and have enabled accounting tasks to be accomplished much faster and more accurate than hitherto.

[14] also affirmed that technology; information system and electronic data processing (EDP) have changed the way organizations conduct its business, promoting operational efficiency and aid decision-making.

\subsection{IFRS Implementation: The Need for Information Technology Support}

IFRS cannot be implemented in a vacuum. Its successful implementation has to be premised, inter alia, on the existence of a formidable information technology supporting structure. Any organization that has successfully implemented IFRS had done so to the extent of the effectiveness of its enabling information technology structure. In essence, the absence of this structure, as earlier noted has been one of the key progress limiting factors as far as the issue of IFRS is concerned.

According to [8], IFRS adoption generally cannot be accomplished by finance alone. The involvement of the organization's technology executives and their related functions early in the preliminary planning stages could help potentially costly rework at a later date.

Information technology facilitates the implementation of IFRS through the design and implementation of internal controls to fit with the provisions of IFRS. Information technology support managers are tasked with matters related to the application of computer systems ranging from designing, monitoring, and maintenance of software required to supporting the computerised system of IFRS-based financial statements [21].

There is therefore the need, not only for the preparers, but also for auditors to familiarize themselves with the necessary 
software as well as the changes to existing systems, following the implementation of IFRS by companies in Nigeria.

\subsection{IFRS Implementation: The Changes to Existing Information Technology Systems}

Every system within an organization that uses financial information is bound to be affected by conversion to IFRS. A KPMG report indicates that changes in filing requirements and accounting standards drive conversion to international financial reporting standards (IFRS) in an organization, while the process of conversion impacts on general business information technology systems of that organization [2]. The implementation of IFRS and its disclosure requirements impacts the information technology infrastructure of an organization, particularly source systems, general ledgers, sub-ledgers and reporting mechanisms [13].

[22] noted that on conversion to IFRS, the pre-existing systems would definitely not be able to facilitate the financial information requirements of IFRS. Such development would lead to a reassessment and change of those pre-existing data models. The existing interfaces and underlying databases would need to be adjusted. The company's financial systems and reporting infrastructure would also be changed to suit the changes in accounting policies and financial reporting processes. Where there are changes to the number of consolidated entities, mapping structures and financial statement reporting formats, the consolidation system would also change [22]. In addition, depending on the relationship between the parents and consolidated entity's systems, new electronic interfaces or processes may need to be established [18]. Also, system changes or enhancements maybe required to handle the dual-reporting requirements and modifications may be needed to the configurations of the settings of various financial subapplications, such as fixed assets (depreciation or useful lives) and inventory valuation calculation and master data [6].

As key areas of focal emphasis, [20] summarily identifies four key areas of information technology implications which an organization implementing IFRS must take into consideration:

\section{(a) New data requirements:}

IFRS mandates more comprehensive and detailed disclosures in financial reports. To capture this level of detail, organizations require information technology systems that are capable of tracking more granular information across a range of new data fields.

(b) Data storage and retention:

The organization implementing IFRS still need access to its legacy financial systems to comply with data retention requirements. This raises questions around the company's ability to effectively store and retrieve mass amounts of older financial data. It also has implications around the retrieval of data for comparative purposes, benchmarking and other business decisions that involve comparison of data.

(c) Application level controls:

Any migration to a new financial reporting system will alter the way in which an organization processes transactions.
In addition to mandating revised business process controls, this shift will result in the need to amend the organization's general application environment to ensure that security, authentication and access control mechanisms remain sufficiently robust to meet regulatory requirements.

(d) Implications on business intelligence and decisionmaking systems:

This is concerned with the way in which data is shared across the organization's enterprise-wide operational systems. As the organization's financial data input evolves to comply with IFRS, the information that feeds into its operational systems may shift as well. As such, companies and organizations may find that they have to amend key inputs into the systems responsible for such things as forecasting and budgeting, performance management, incentive-based compensation, decision-support tools or taxrelated reporting. In essence, consideration should be given to the likely need to change the applications to support IFRS data collection and financial reporting.

[17], the detailed reporting required in IFRS puts more pressure on information gathering and could uncover hidden management reporting aspects of business model in addition to increasing costs and time spent on information accumulation. It follows therefore that the transformation to IFRS is a multi-dimensional, long-range process that usually involves both short- and long-term initiatives, one of which is the issue of information technology.

[13], also added that, conversion to IFRS could also be an added incentive to modify or replace existing systems that are not delivering adequate or timely information, especially for organizations involved in transformational initiatives such as enterprise resource planning, which rely on comprehensive financial reporting.

Information technology typically represents the most significant costs of IFRS conversion. In view of these, some small organizations and those embarking on cost saving measures may choose to adapt existing information systems in the short term [13]; taking cognizance of the dimensions of information technology impact that the organization is likely to face. To assess potential changes due to IFRS requirements, an organization should identify changes in financial information requirements and the impact of these requirements on existing management information systems, such as valuation systems and actuarial models [6].

\subsection{IFRS Implementation: The Determinants of Impact on Information Technology Systems}

The impact of IFRS implementation on the information technology structure of any organization varies depending on the organization's existing structure and environment. This may include its information technology and financial systems capability/integration, industry complexity, company size, relevance of business process/transaction, internal control structure, mergers and acquisitions process, and other attributes [4].

The extent to which systems will need to change depends upon multiple factors and choices, including the quantity and 
nature of accounting changes driven by IFRS, size and complexity of the business, strategy for responding to IFRS, characteristics of the current infrastructure and capabilities and number of applications that are involved in the collection of financial data and the generation of financial statements [6].

[8] agrees that the extent to which systems will need to change depends upon multiple factors and choices: the size and complexity of the business, the strategy for responding to IFRS, characteristics of the current infrastructure and capabilities and number of applications that are involved in the collection of financial data and the generation of financial statements. [20] also shares a similar view that the issue of IFRS compliance affects each organization differently, depending on the complexity of its business structure, and accounting and reporting systems.

\subsection{IFRS Implementation: Information Technology Challenges to Audit Practice}

\subsubsection{Auditors' Technical Expertise}

According to [1], the practical implementation of IFRS requires adequate technical capacity, not only among preparers and users of financial statements but also among auditors and regulatory authorities. [2] notes that there are no enough professionals who are able to interpret and translate the IFRS requirements into information technology changes and solve the technical issues involved in conversion. Auditors are expected to understand how the system processes and produces accounting information and what controls are operating in the system [16]. However, some auditors also face the challenge of this know-how deficiency. Auditors face the challenge of keeping pace with emerging technology and infrastructure changes, including transformation, innovation and disruption [12].

\subsubsection{Audit Complexity and Time Efficiency Issues}

IFRS is an accounting and financial reporting framework that requires more judgment and less reliance on detailed rules. This judgement based approach suggests that there are many ways of arriving at a reasonable valuation [15]. The finding of a study by [17] also corroborates the fact that IFRS adds to financial reporting complexities and increase compliance with accounting standards. The preparers of IFRS reports must explain the impact of adoption on the organization's former GAAP. Put differently, IFRS has fewer rules than the local GAAP, this places more challenge of judgement back in the hands of preparers and auditors. The auditor is faced with the challenge of having to be more thorough and punctilious. All these add a new dimension to audit task that can be time-consuming and complicated [10].

\subsubsection{Audit Execution Costs}

Auditing as a profession is rigorous, challenging, complex and ever-changing [8]. Auditors and their assistants therefore, have to be well equipped with relevant knowledge and skill in order to enhance audit effectiveness and quality. On the part of the auditor, relevant changes in clients' organizational information technology systems structure; in order to meet IFRS implementation needs; increase the cost of training audit staff/assistants for qualitative audit service delivery.

\subsubsection{Audit Detection Risks and Errors}

According to [14], rapid development of information technologies causes continued worry about new auditing risks. The Information technology changes induced by IFRS pose a risk of possible systematic errors in audit. In the course of audit planning, auditors face the challenge of critically review all the areas of high risk in order to ensure that the planned procedures adequately cover such high risk areas (http://icanig)

\subsubsection{Audit Strategy Reviews}

The dynamic nature of IFRS and the Information technology implications arising from its implementation confronts auditors with a consistent challenge of reviewing their audit strategy and processes (planning, testing and documentation) to keep in pace with expectations.

\section{Methodology}

The survey research design is adopted for the study. The population of the study consists of auditors in audit and accounting firms in Anambra and Akwa Ibom states of Nigeria. One hundred and twenty (120) auditors are randomly selected from this population using convenience and judgemental technique. This constitutes the study sample. The study employs basically primary data sourced through a five point Likert scale questionnaire distributed to the study respondents. The data collected are analysed using the descriptive statistic such as averages, weight and ranking.

\section{Data Analysis and Results}

One hundred and six (106) copies of the questionnaire were completed and returned giving a response rate of $88.33 \%$. The analysis shows that the respondents have an average of over five years experience in audit practice and that $92 \%$ of the respondents are IT literate. The result of the analysis shows that the emerging technology and infrastructure changes arising from IFRS implementation which requires high IT expertise from auditors is the greatest challenge confronting the auditors with $92.5 \%$ in the affirmative. (see Appendix).

Next in line with $87.5 \%$ is the fact that understanding up to date computerized systems and software arising from IFRS implementation is a challenge. It is revealed that changes in IT structure in order to meet IFRS implementation had increased the cost of training audit staff for audit assignments. Also, the technical expertise to keep pace with the resultant infrastructural changes is a huge challenge $(84.2 \%)$; this aligns with the findings of [15]. The other identified challenges are that expectations for IFRS implementation have resulted in new dimensions of audit task which is time consuming and there is an increased 
problem with coping with adjustment of the existing interfaces and underlying database. The least challenge faced by the auditors is coping with IT internal control systems as a result of IFRS implementation and it is ranked next behind the change of possible systematic errors in audit as a result of IT changes induced by IFRS.

Other IT implications of IFRS implementation on audit practice in Nigeria identified include: the issue of accounting for post- employment benefit schemes; synchronizing client's systems with Computer Aided Audit Technique (CAAT) and lack of the required auditing software. This has made audit task complex creating difficulties in impairment test for tangible and intangible assets; and in liability adequacy tests.

\section{Conclusion}

The result of the analysis shows that the emerging technology and infrastructure changes arising from IFRS implementation which requires high IT expertise from auditors is the greatest challenge confronting the auditors. Also, the cost implication of changing IT infrastructure poses another challenge to auditors. Both accountants and auditors should brainstorm and develop cost-effective software that will meet and address the IT/IFRS challenges. Hence, auditors should take up the challenge of updating their knowledge and skills with regard to IFRS and information technology in order to brace up for the challenges ahead. This will enable auditors to provide more reliable, accurate, transparent, valid and quality audits of financial statements. The curriculum of accounting training institutions and professional tuition houses should be updated to meet up the challenges of IFRS implementation.

Table 1. Results of responses to a structured questionnaire.

\begin{tabular}{|c|c|c|c|c|c|}
\hline & & SCORES & AVERAGE & WEIGHT & RANKING \\
\hline 1 & $\begin{array}{l}\text { The emerging technology and infrastructure changes arising from IFRS implementation } \\
\text { require high IT expertise from auditors }\end{array}$ & 494 & 4.66 & 0.925 & $1 \mathrm{ST}$ \\
\hline 2 & $\begin{array}{l}\text { Understanding of up to date computerized systems and software arising from IFRS } \\
\text { implementation is a challenge }\end{array}$ & 464 & 4.38 & 0.875 & 2ND \\
\hline 3 & $\begin{array}{l}\text { Technical expertise to keep pace with infrastructural changes resulting from IFRS } \\
\text { implementation is huge challenge }\end{array}$ & 446 & 4.21 & 0.842 & $4 \mathrm{TH}$ \\
\hline 4 & The IT implications of IFRS implementation makes auditing more complicated & 414 & 3.91 & 0.781 & $8 \mathrm{TH}$ \\
\hline 5 & $\begin{array}{l}\text { There is an increased problem with coping with adjustment of the existing interfaces and } \\
\text { underlying database as a result of IFRS implementation }\end{array}$ & 432 & 4.08 & 0.815 & $6 \mathrm{TH}$ \\
\hline 6 & $\begin{array}{l}\text { Expectation for IFRS implementation has resulted in new dimensions of audit task } \\
\text { which is time consuming }\end{array}$ & 438 & 4.13 & 0.826 & $5 \mathrm{TH}$ \\
\hline 7 & $\begin{array}{l}\text { Changes in IT structure in order to meet IFRS implementation needs increase the cost of } \\
\text { training audit staff/assistants for audit assignment }\end{array}$ & 462 & 4.36 & 0.872 & $3 R D$ \\
\hline 8 & The IT changes induced by IFRS pose the chance of possible systematic errors in audit. & 400 & 3.79 & 0.755 & $11 \mathrm{TH}$ \\
\hline 9 & $\begin{array}{l}\text { The modifications and configurations of the settings of various financial sub- } \\
\text { applications have been great challenges with IFRS implementation. }\end{array}$ & 416 & 3.92 & 0.785 & $7 \mathrm{TH}$ \\
\hline 10 & $\begin{array}{l}\text { The dynamic nature of IFRS and the IT implications arising from its implementation } \\
\text { necessitates regular review of audit strategy and procedures }\end{array}$ & 410 & 3.87 & 0.773 & $10 \mathrm{TH}$ \\
\hline 11 & $\begin{array}{l}\text { Coping with IT internal control systems as a result of IFRS implementation is pretty } \\
\text { difficult }\end{array}$ & 386 & 3.64 & 0.728 & $12 \mathrm{TH}$ \\
\hline 12 & $\begin{array}{l}\text { The chances of audit risks are higher as a result of the IFRS induced changes to IT } \\
\text { systems }\end{array}$ & 414 & 3.91 & 0.781 & $8 \mathrm{TH}$ \\
\hline
\end{tabular}

\section{References}

[1] Abata, M. A. (2015). Impact of IFRS on financial reporting practices in Nigeria (A case of KPMG). Global Journal of Contemporary Research in Accounting, Auditing and Business Ethics (GJCRA): An Online International Research Journal (ISSN: 2311-3162). 1(1), pp 264-281. Retrieved on, 20-62016 from www.globalbizresearch.org.

[2] Accounting Web (2008). Conversion to IFRS will challenge information systems and IT personnel.

[3] Adetula, D. T., Owolabi, F. \& Ifeoma, O. O. (2014). International Financial Reporting Standards (IFRS) for SMES adoption process in Nigeria. European Journal of Accounting, Auditing and Finance Research. 2(4), pp. 33-38, June 2014.

[4] AICPA (2010). IFRS Primer for Audit Committees. Audit
Committee Brief from the Audit Committee Effectiveness Centre. June 2010.

http://www.ifrs.com/overview/board audit/aud-com jun2010_1final.pdf.

[5] Ayuba, A. (2012). A proposed rule - Roadmap for the adoption of International Financial Reporting Standards (IFRS) in Nigeria: A research based perspective on FGN, NASB \& SEC. American Journal of Economics. June 2012, Special Issue: 41-45 DOI: $10.5923 /$ j.economics.20120001.10.

[6] Barile, J. (2011). IFRS Compass: IT Systems Implications.

[7] Batra, K. (2015). Role of Internal Auditors in transition to IFRS. Chartered Club.

[8] Delloitte (2008). Technology implications of IFRS adoption for U.S. Companies.

[9] Delloitte (n.d) IFRS implementation services: Implications of an accelerating global trend. 
[10] Dulitz, L. (2009). IFRS: A preparer's point of view. Journal of Accountancy.

www.journalofaccountancy.com/issues/2009/apr/preparerspoi ntofview.html.

[11] ICAN Pack. Audit planning and control. Advanced Audit and Assurance. http://icanig.org/documents/aaa.pdf.

[12] ISACA (2015). Top 10 technology challenges for IT audit professionals - New study from ISACA and Protiviti. PressRoom $>$ NewsReleases. www.isaca.org/AboutISACA/Press-room/News-Releases/2015/Pages/Top-10Technology-Challenges-for-IT-Audit-Professionals-NewStudy-from-ISACA-and-Protiviti.aspx?utm_referrer=.

[13] Khoury, S. (2009). Public, private or non-profit: How IFRS can add value to your Information Systems.

[14] Moorthy, M. K., Seetharaman, A., Mohamed, Z., Gopalan, M. \& San, L. H. (2011). The impact of Information Technology on Internal Auditing. African Journal of Business Management. Vol 5(9), pp 3523-3539. Available online at http://www.academicjournals.org/AJBM DOI: 10.5897/AJBM10.1047.

[15] Nyor, T. (2012). Challenges of converging to IFRS in Nigeria. International Journal of Business Information Technology. 2(2), June 2012

[16] Odum, A. N. (2010). Essentials of Auditing and Investigations. Nimo: Rex Charles and Patrick Ltd, pp 259.
[17] Okafor, C. \& Ogiedu, K. O (2011). Potential effects of the adoption and implementation of International financial Accounting Standards (IFRS) in Nigeria. Journal of research in National Development. Vol 9(2). www.ajol.info/journals/jorind.

[18] PwC (2012). Mapping the change: IFRS Implementation Guide. IFRS Readiness Series. www.pwc.com/usifrs.

[19] Saidu, S. \& Dauda, (2014). An assessment of compliance with IFRS framework at First-Time Adoption by the quoted Banks in Nigeria. Journal of Finance and Accounting, 2014, Vol. 2, No. 3, 64-73 Available online at http://pubs.sciepub.com/jfa/2/3/3 C Science and Education Publishing DOI:10.12691/jfa-2-3-3.

[20] Steele, D. (2009). The IT Implications of IFRS. Grant Thornton Article. www.grantthornton.ca.

[21] Suryanto, (2015). Analysis the use of International Financial Reporting Standards (IFRS) in PT Telekomunikasi Indonesia, TBK. European Journal of Accounting Auditing and Finance Research. Vol 3(3), pp 86-98. Published by European Centre for Research Training and Development UK (www.eajournals.org).

[22] Taiwo, F. H \& Adejare, A. T. (2014). Empirical analysis of the effect of International Financial Reporting Standards (IFRS) adoption on Accounting Practices in Nigeria. Archives of Business Research, 2(2), 1-14. 